\title{
Lean-Excellence Business Management for Manufacturing SMEs focusing on KRI
}

\begin{tabular}{|r|l|}
\hline Journal: & International Journal of Productivity and Performance Management \\
\hline Manuscript ID & IJPPM-11-2018-0389.R2 \\
\hline Manuscript Type: & Standard Paper \\
\hline Keywords: & LEBM framework, Lean-excellence, Business Management, SMEs, KRI \\
\hline \multicolumn{2}{|l}{} \\
\end{tabular}




\section{Lean-Excellence Business Management for \\ Manufacturing SMEs focusing on KRI}

Purpose: This paper aims to develop an effective framework for implementing Lean strategies in Small and Medium-sized Enterprises (SMEs) in the Kurdistan Region of Iraq (KRI).

Methodology: Based on the integration of LM tools and techniques with the MBNQA criteria a systematic lean implementation framework for manufacturing SMEs has been proposed. The core values, drivers and tools of the proposed framework were further developed based on case studies in three SMEs in the KRI.

Findings: Proposed framework is able to provide a simple pathway for SMEs to systematically implement Lean techniques in seven functional areas in order to create Lean culture in the organisation. Business performance measurement in terms of profitability, customer satisfaction, employee's satisfaction, competitiveness growth and ergonomic improvement are presented in favour of evaluating Lean outcomes appropriately. it also presents the experience of small firms in implementing lean programmes to show that Lean is valid in SMEs.

Implications: The framework assists improvements for SMEs that either attempt to start lean journey or those that are at more advanced levels towards excellent-lean manufacturing. The framework can also be used as a self-assessment model to determine the degree of lean readiness.

Limitation: The framework concentrates only on the internal issues of the organisation, while external variables such as national culture and external support are excluded.

Originality: To the best knowledge of the author, it is the first framework that integrates Lean techniques with MBNQA criteria to support Lean implementation in SMEs. It is also the first study regarding Lean-excellence in the KRI.

Keywords: LEBM framework, Lean-excellence, Business Management, SMEs, KRI.

\section{1- Introduction}

The current global hyper-competition and swift technological changes are forcing many companies to optimise their production processes that enable them to produce 
high-quality and low-cost products. This quest has increased the necessities for extensive improvements in manufacturing leadership, customer relationship, process management, strategic thinking, and employees satisfaction (Mason et al., 2015; Netland, 2016; Alhuraish et al., 2014; Alaskari et al., 2012). LM thinking is a philosophy that addresses advantages obtained from the mentioned sources. The core idea of LM is to build mutual trust, and unique way of working that ensures highly responsive to customers' demands while constantly cutting cost and eliminating wastes throughout the organisation (Bhamu \& Sangwan, 2014; Shah and Ward, 2003).

To generate the best possible values and reduce non-value added activities, manufacturers applied different LM principles, tools and techniques. However, many organisations find it complex and difficult to do that effectively (Baker, 2002). In the context of SMEs, LM initiatives pose further challenges. Lack of adequate finance, leadership deficiencies, shortage in multi-skilled employees, short-term orientation, inappropriate organisational culture and outdated manufacturing technologies come in the forefront of these barriers (Sahoo and Yadav, 2018; Antosz and Stadnicka, 2017; Jasti and Kodali, 2014; Achanga et al., 2006).

In the KRI, SMEs which account for $95 \%$ of the manufacturing sector and employ $80 \%$ of the industrial labour force play a vital role in the development of the economy (KRG-MOP, 2012). However, KRI-SMEs have currently faced a lot of difficulties caused by imported products from the regional countries, and the collapse of the oil revenue which caused a national economic slowdown. Since 2014, the number of dissolved SMEs has been steadily rising while the remaining firms have been struggling for survival (Shehab et al., 2017). Therefore, developing a holistic framework to improve SMEs productivity is an immediate quest of SMEs managers and researchers in the KRI.

In the literature, various studies have been carried out in proposing frameworks to improve productivity of SMEs by LM, but they are often conceptual, complex in structure, incomplete, have no clear links between outlined elements, cannot engage shop floor workers, and cannot measure the outcomes of LM (Belhadi et al., 2016; Nguyen, 2015; Mostafa et al., 2013; Anvari et al., 2011). Therefore, this paper argues and discusses how MBNQA can be used as an overarching framework for implementing LM initiatives within SMEs to achieve improvements in business 
performance. In an attempt to assist KRI-SMEs to implement LM successfully, this research develops a new framework by integrating Lean tools with MBNQA criteria which is believed to be valuable and suitable for them.

To fulfil the aim of this study, three main objectives were developed: (1) to show that integration between Lean techniques and MBNQA criteria is possible and it can provide all requirements of successful Lean adoption in SMEs. (2) to examine the process of Lean implementation in manufacturing SMEs through case studies. (3) to identify a set of critical success factors and comprehensive Lean tools that support SMEs to implement Lean effectively.

The proposed framework is called Lean-Excellence Business Management (LEBM). It was developed after conducting a literature review related to the possibility of a combination of Lean tools with MBNQA criteria to support SMEs development. The core value, drivers and operation tools are reviewed and checked in the light of case studies conducted in three manufacturing SMEs in the KRI. It is assumed that the framework would provide insights and guidelines to SMEs in general and in the KRI, in particular, to implement a Lean approach effectively.

The rest of this paper is organised as follows: First, the review of the literature about the LM application in general and within SMEs in particular, review of LM framework for SMEs and MBNQA model is presented. Next, the integration between LM and MBNQA, and their synergistic benefits are examined. Secondly, the methodology and rationale of the literature review and case studies are discussed. Then, the findings from the case studies and an overview of the development of the framework is provided. Finally, the characteristics and application of the new framework, the main conclusions from this study, and some possible opportunities for further research were suggested.

\section{2- Literature review}

\subsection{Lean Manufacturing application}

The implementation of LM like other productivity improvement initiatives needs systematic processes to apply correct Lean tools within different organisational areas in order to achieve excellent business performance. However, the processes are not outright to follow, as each organisation has its own culture and policies that might support or resist the flow of Lean activities (Anvari et al., 2011). 
To avoid costly defeats and support organisations to adopt LM, practitioners and researchers have suggested a list of critical success factors (CSF). CSF are those few organisational areas that need constant attention to go well in order to bring success for the companies.

In the literature, the most common CSF of effective lean adoption have been highlighted are top management and leadership, human resources, strategic planning, customer focus, LM knowledge and process management (Alhuraish et al., 2014; Netland, 2016; Alaskari et al., 2012; Rose et al., 2011). Other researchers highlighted different aspects such as visual management, deep understanding of LM principles (Nugyen, 2015), risk management (Jedynak, 2015), internal competence and appraisal system (Ottar et al., 2011), quality improvement and housekeeping (Upadhye et al., 2010), product design and supplier development (Wong et al., 2009), managing culture change, infrastructure and reward systems (Ahuja and Khmaba, 2008), financial ability and expertise participation (Achanga et al., 2006), personal values, beliefs, and ideologies that affect the behaviours of the workers in an organisation (Wong and Cheah, 2011), situational analysis, LM learned lessons review, LM assessment and LM sustaining (Mostafa et al., 2013). Table 1 summarised the most frequent CSF in the literature.

Top management commitment and total employees' involvement to the LM changes come at the top of those factors that support successful LM implementation. Managers have to communicate strategies, facilitate, model the behaviours of LM and share their vision, understanding and experience with the shop-floor employees to pave the pathway to trust, directly adapt and sustain the improved outcomes (Kumar, 2014). Clear Lean strategies and staff training also highlighted frequently. LM system needs a constant and long-term vision to create incremental improvements to the manufacturing processes. LM transformation does not happen overnight: it is an overall change in all areas of the company, regularly giving and receiving feedback, not just the one-course solution. The journey requires continuous training and education to facilitate the process of the intended change (Crute et al., 2003).

\section{Table 1}

\subsection{Lean application in SMEs}


LM practices in SMEs have a relatively short history (Matt and Rauch, 2013). Some researchers argue that full LM programmes are more likely to be implemented in big businesses rather than SMEs (Ottar et al., 2011; Rose et al., 2011; Shah and Ward, 2003). Achange et al. (2006) also believe that SMEs are still not sure about the cost of LM implementation and the tangibility of its outcomes and benefits they may achieve. Most of these companies fear that adopting LM are time and moneyconsuming.

Hayes (2005) argued that successful adoption of LM projects in SMEs requires previous stability in the organisation and assurance of budget, human resource, training, programmes, strategic planning and reward mechanics. Nguyen (2015) declared that SMEs have to start with the simple and less financially demanding LM tools such as 5S, kaizen and visual control. After that, they can extend to more advanced tools such as kanban and small lot size. He clarified that LM practices mostly depend on human mindset and the workforce behaviours. Thus, the SMEs have to start firstly with raising their employee's awareness of LM nature and requirements.

Mason et al. (2015) reviewed 101 papers (until February 2015) regarding different practices of LM in the SMEs and found that all researchers confirmed positive results regarding quality and productivity. They concluded their review as follows:

- LM initiatives in SMEs are closer to the internal process improvement and are not extended to cover the whole supply chain. They are likely JIT production rather than JIT delivery.

- Simple and inexpensive techniques such as Value Stream Mapping (VSM), 5S, Kanban, Standardisation and Total Productivity Maintenance (TPM) are mostly used while other tools such as Accounting Methods, Cellular Manufacturing, Project Management, and Quality Function Deployment (QFD) are applied less.

- LM practices in SMEs often aimed to reduce waste, inventory, time, and cost or to increase product quality, and rarely covered customer relationship and supplier management.

- Factors such as leadership, strategic planning, employee involvement, organisational cultures, employee autonomies, wide communication, training and education, willingness to change are the most CSF for SMEs to perform LM. 
- Most of the LM inhibitors are related to the unclear vision toward lean, market demand fluctuation, raw material control, weak customer links, poor production processes, weak quality control system, unaided organisational culture, and lack of funding.

Regarding the implementation of Lean tools and techniques, Matt and Rauch (2013), and Sahoo and Yadav, 2018 stated that even if not all lean techniques are applicable in SMEs, a selection of a suitable method can be recommended as follows:

- First-in-first-out (FIFO)

- $5 S$ (Seiri, Seiton, Seiso, Seiketsu, Shitsuke)

- Benchmarking

- Kaizen - Continuous Improvement meetings

- Just in Time delivery

- Pull-principle and Kanban

- Visual Management in Production

- Zero Defect through process-integrated failure control

- Idea Management to utilise the worker's Know-How

- Setup Time Reduction to reduce waste

- Value Stream Mapping

- Efficient and ergonomic workstations

- Poka Yoke and standardisation in product and process

- Cellular Manufacturing and autonomous teams

- Job rotation to avoid monotony

- Low-Cost automation (“keep it smart and simple”).

To implement Lean initiatives in small organisations successfully; therefore, a practical framework that covers all Lean pre-requirements, CSF and correct tools are necessary (Balles, 2005; Esfandyari and Osman, 2010).

\subsection{Review of the Lean implementation frameworks}

According to Sousa and Aspinwall (2010), the framework is a presentation of the structural relationship of variables of a particular system aims to answer "how to" questions and steers the methodology implementation. Regarding Lean framework, 
Anvari et al., (2011) claimed that it should guide the transition from existing production processes to one that ultimately follows the best practices of LM philosophy. While Wong and Wong (2011) defined LM framework from the organisational perspective when argued it has to integrate the best practices in different areas of the company to allow practitioners to understand the full requirements of LM transformation.

Al Manei et al., 2017; Bilhadi et al., 2016; Nguyen, 2015; Jasti and Kodali, 2014; Karim \& Arif Uz-Zaman, 2013; Wong and Wong, 2011; Rose et al., 2010 have developed different frameworks to guide organisations on how to implement Lean projects. These frameworks often highlighted Lean tools and success factors to be introduced to the organisation. Table 2 presents the review of a number of the frameworks and their shortcomings in the context of SMEs.

\section{Table 2}

The researchers in Table 2 have criticised the existing framework in the literature because they are complex in structure, and have no clear links between their components (Bilhadi et al.,2016), top-down approach and cannot engage the shopfloor workers (Nguyen, 2015), quite generic and do not specify the sequences of LM implementation (Rolish and Shahadat, 2014). However, they cannot overcome all these weakness and deficiencies in their developed frameworks. The conceptual framework of Mostafa et al. (2013) has a complex structure of 22 steps, which is hard for SMEs to follow and needs highly-skilled workers to implement. A methodology of LM implementation of Halim et al. (2013) which is based on Toyota's eight steps processes is designed for large enterprises (LEs) and is not suitable for SMEs, especially for beginners. The project-based framework of Anvari et al. (2011) limited most of the LM activities to the top managers, and the role of the workers is not clear. This framework needs a lot of effort to sustain the results which is not easy for SMEs to provide.

This research, therefore, argues that an overarching framework like MBNQA can provide a holistic and simple methodology for LM implementation. LM principles and techniques can easily integrate into the criteria of the framework to generate a new framework that can enhance productivity through the improvements in manufacturing processes in SMEs. An overview of the MBNQA model, thus, here is essential.

\subsection{Malcolm Baldrige National Quality Award (MBNQA)}


MBNQA is one of the well-known business-excellence awards which aim to recognise and reward business excellence across all sectors in many countries. It was released in 1987 to improve the quality of the American products to compete in an ever-expanding global market. Initially, the reward covered manufacturing, service and small companies; from 1998, it also covered education and healthcare associations. Since 2006, non-profit organisations have also been eligible to participate in it (MBNQA, 2017a). As a result, more than 2 million companies in 100 countries have produced their versions of the award (BPEP, 2013).

This model is systematic and documented best practices that can create an environment for continuous improvement and guide an organisation toward excellent performance at both strategic and short-term extents (Tickle et al., 2016; Sharma and Kodali, 2008). Furthermore, it is a globally accepted model, imitated by 27 national awards around the world (16 of them in Asia). Thus, the model is adaptable to the various types of organisations despite their size, economies and cultures. Figure 1 presents the criteria of MBNQA.

\section{Figure 1}

MBNQA model has been adopted as a catalyst to improve competitiveness and develop the culture of quality rather than just an award of excellent performance. It consists of seven integrated dimensions which namely are Leadership, Strategy, Customers, Measurement, Analysis and Knowledge management, Workforce, Operations, and Results of the business.

It allows managers to appreciate all the factors influencing their organisations, to prioritise, develop, and improve essential issues to success, and to establish practices that enhance and sustain the best possible performance (MBNQA, 2017b).

MBNQA is a non-prescriptive qualitative framework; it does not prescribe any specific methodology or action plan to be followed. Fischer (2010) and Parasat and Jones (2006) claimed that MBNQA could provide a comprehensive framework that enables enterprises to eliminate wastes or to streamline their production processes. So, LM can efficiently address opportunities within all of the MBNQA criteria (DeVries, 2014).

\subsection{Integration of Lean tools with MBNQA criteria}

To support lean transformations of enterprises, many researchers suggested integrating LM principles with other advanced methodologies such as Six Sigma, 
Balanced Scorecard and Business Excellence models (Okhovat et al. 2012; Blazey and Grizzell, 2014). Combination of LM tools with MBNQA frameworks can bring better results in terms of quality (Soare, 2012), problem-solving, improving organisational performance (Motwani, 2003), speed up delivery, reduce cost (Ho, 2010) and cut down processing time (Tatsana-iam and Ngaoprasertwong, 2013). The core idea of this research, therefore, is to combine Lean techniques and MBNQA criteria into a single framework to support a systematic lean implementation within SMEs context.

Although the MBNQA and LM follow different development paths, they have some similarities (Anvari et al., 2011; Dahlgaard and Dahlgaard-Park, 2006) and overlapped objectives (Parast and Jones, 2006). They share common concepts such as continuous improvement (Pettersen, 2009), organisational learning (Bozdogan, 2010), process improvement and customer satisfaction (Andersson et al., 2006) and employee involvement, empowerment and well-being (Grizzell and Blazey, 2006). Table 3 explains the harmony between the MBNQA criteria and LM approach.

\section{Table 3}

The MBNQA focuses on the critical factors driving excellent business performance, while LM emphasises on eliminating waste through the improvement of the valueadded processes. Thus, both have similar objectives. When LM reduces waste from the production process, it promotes the MBNQA's aim of continuous quality improvement (Bozdogan, 2010).

So, The combination of these two strategic approaches into a single framework will bring further advantages to small businesses and can accelerate their transition toward lean-excellence performance.

\section{3- Methodology}

Literature review presented in the previous sections confirmed the applicability and advantages that can be achieved from the integration of Lean tools and MBNQA model, but the framework has to be tailored to the specification and limitations of SMEs. For this reason, the conceptual framework is derived from the literature reviewed and validated through the case studies that have been conducted in three manufacturing SMEs in the KRI. Figure 2 shows the methodology undertaken in this research.

\section{Figure 2}


Case studies allow researchers to discover intangible factors that can entirely explain how the system functions and draw more clear portraits of complex issues which are always not available for other research methods (Stake, 2006). It often follows a wide range of open-ended techniques in data collection and analysis such as structured and unstructured interviews, observation, documentation analysis (Saunders et al., 2009). Thus, the method is valid for this study. Moreover, researchers such as Bilhadi et al., 2016; Karim and Arif uz-Zaman, 2013; Wong and Wong, 2011 and Aken et al., 2010 also followed the case study method to develop frameworks that assist SMEs in implementing Lean approach.

The selected companies for the case studies used different lean tools such as $5 \mathrm{~S}$, Work Teams, Total Productivity Maintenance (TPM), Quality Assurance (QA), 5 Whys, Quick customer feedback, Cross Employees Training and Reward and Motivation activities. They effectively manage waste, time, inventory, raw material and workforce efforts in their companies. They also employ modest technologies in their production and control processes. They are well-known, successful, competitive and leading companies in their industrial market in the $\mathrm{KRI}$, and employ highly skilled workers. So they can be taken as lean models in the region. Details of participant companies are presented in Table 4.

\section{Table 4}

To offer a good range of information, the researcher asked selected persons of the participating companies to get involved in a semi-structured interview which aimed to explore the working environment and managerial style deeply. They were previously motivated to understand the aim of the study, to feel free to provide any responses and comments they preferred and to prepare well for the interview date to ascertain the accuracy of the provided information.

The case studies focused on several aspects which namely are: Core values and ethical principles that motivate them to commit to their production requirements, the MBNQA criteria in their working environment, application of Lean tools and techniques, and their main production problems.

\section{4- Findings of the case studies}

In this section, a summary of the participant's responses is presented in order to meet the cognitive objectives of the present study. Note that a $(\checkmark)$ indicates that the 
element was applied by the company while $(X)$ means that it was not.

\subsection{Core values and principles considered in KRI-SMEs}

As to the core values and ethical principles, the enterprises in which the case studies were conducted all depended on values such as customer focus, valuing people and continuous improvement to run their LM activities. While other principles such as management by the fact, transparency and flexibility are more applicable to company $\mathrm{C}$ than companies $\mathrm{A}$ and $\mathrm{B}$. Table 5 shows the core values adopted by KRI-SMEs.

\section{Table 5}

\subsection{LM drivers (MBNQA criteria) applied to KRI-SMEs}

Table 6 presents Lean drivers or MBNQA criteria that were considered in the focused companies in order to implement effective Lean within their environment. As can be seen, managerial areas of the customer relationship, continuous improvement, human resource development and internal process management are emphasised by all companies. Each company applied its available LM techniques in those areas in order to generate the best performance. Effective lean leadership, long-term planning and measuring business performance were absent within companies $A$ and $B$, while Company $\mathrm{C}$ which has more resources, skills and experience applied lean techniques within these managerial sources.

\section{Table 6}

\subsection{CSF and Lean tools implemented in KRI-SMEs}

This part of the case studies aimed to identify CSF that lead LM implementation and to describe Lean tools and techniques implemented by KRI-SMEs. Table 7 summarises the participant's opinions in this regard.

It is clear that all case companies considered top management commitment, longterm vision, reward and motivation, total employees involvement, and supplier relationship to support the implementation of LM in their companies. It is also worth mentioning that all participants were not satisfied with lean strategies, deep understanding of the LM approach and employees empowerment in their companies. Product Customisation, 5S, Total Productivity Maintenance, and Automation were the common Lean techniques applied to KRI-SMEs while Visualising Stream Chain has 
not been applied in any of the case companies. Company $\mathrm{C}$ applied Statistical Process Control, PDCA cycle and customer data to eliminate non-value added activities within its production processes.

\section{Table 7}

\subsection{Problems facing KRI-SMEs in implementing LM initiatives}

Implementing LM techniques in KRI-SMEs is proceeding slowly, as they face difficulties in various managerial areas. Table 8 shows the common problems that KRI-SMEs have in adopting LM techniques. Language barriers, unfavourable organisational culture, low qualified workers, poor banking system and strong market competition were the main difficulties that faced the case companies. However, there is evidence in favour of LM use to improve quality, reduce wastes and delivery time, and increase productivity.

\section{Table 8}

\section{5- Development of LEBM framework}

Responses and general practices obtained from the case companies were generalised and were combined with a literature review to build a framework. The framework consists of core values as foundation and pre-preparation for Lean implementation, seven key drivers for Lean performance improvement, five Lean tools under each factor to adopt Lean activities within that area, and five indicators to evaluate the business performance and guide the organisation to the excellent Lean levels. For validation of the framework, the participated companies made inputs and necessary modifications.

Figure 3 shows the LEBM framework developed with a focus on SMEs conditions. In order to keep it manageable and straightforward, clear elements are created.

\section{Figure 3}

Generally, the framework is a strategic result-based approach that can help managers to systematically implement specific actions in all managerial areas across the company to transfer their plants from the traditional to Lean-excellent producers. The framework consists of four levels:

- Core values: Values and ethical principles that motivate identification and 
commitment to the framework requirements. These values must be understood before implementing Lean as they are the foundations of Lean thinking and acting for all members of the organisation.

- Drivers: Critical success factors that cover all managerial areas across the organisation and are the determinant for excellent performance. Drivers of the system can be classified into two basic elements; first, a social element which covers leaders, customers and the workforce. Second, a technical element that includes strategies, manufacturing processes and organisational learning.

- Processes: Lean techniques that seek improvement opportunities through drivers. Time, money and efforts need to be invested in educating and training the members of the organisation to select and apply the right techniques at the right time in order to generate the expected outcomes from the driver's area.

- Results: Expected development output of lean-excellence through the effective application of the lean tools from drivers.

As continuous improvement is core conjoint principle between LM and MBNQA and strongly recommended by both approaches (Mahmud and Hilmi, 2014; Okay and Semiz, 2013; Al Amin, 2013), it takes a central role in the LEBM model. It must, therefore, be seen as a systematic driver of all other activities in the organisation.

The LEBM aims to increase the understanding of SMEs on how to comprehensively evaluate their current situation, find gaps and identify the correct lean tools to overcome their process problems. It can play three important roles for manufacturing SMEs, as follows:

- Strengthen organisational competitiveness

- Promote organisational performance, capabilities and results

- Serve as a working tool for better understanding, leading and implementing the organisation's aspiration to learn.

The LEBM model shows the approach for deployment of lean practices. Lean leadership directly or indirectly affect all system constructs by managing lean projects, lean strategic planning, organisational learning and human resource development infrastructure. They should always practice lean principles, simplify the problems, and play good lean role models so that the employees understand what 
actually Lean means in real life and also to emulate their managers to deal with the manufacturing processes. Moreover, they have to value feedback from the customers and employees. A fair reward system and effective suggestion scheme are also needed to motivate them to provide more ideas for better improvements.

Process management, continuous improvement and customer relationship management are key drivers for LM practices. Understanding the current situation, identifying errors, problems and defects accurately, visualising the manufacturing process will reveal the weaknesses and create more development opportunities. Nevertheless, collecting reliable information, conducting in-depth analysis, communicating and sharing experiences will guide correct decisions which eliminate errors and wastes throughout the company.

Business performance evaluates the progress in terms of customer satisfaction, profitability increases, employee satisfaction, competitiveness growth and ergonomics improvement. These indicators are not as equally important as they depend on the characteristics of the enterprise. It must also be obvious to the company that reaching excellence lean performance is an endless journey and continuous improvement is a movement without a destination. Thus, teamwork, trust, tolerance, total employees involvement, and collective responsibility are significant across all phases of lean transformation.

Overall, the framework fulfils requirements for excellent organisational performance which in the end, creates, bolsters and delivers the optimised value for the stakeholders. In addition, benchmarking the outcomes achieved, showing quick advantages, and celebrating bright results obtained will raise the confidence of the employees to Lean approach, decrease their resistance to changes happening and, then, accelerate the transformation processes.

\section{6- Characteristics of LEBM}

LEBM framework is easy to understand, well-structured and consists of strongly interlinked components. It can give visible results in a short time. This model is characterised by the following advantages that make it unique and suitable for manufacturing SMEs in developing countries:

- It is an incremental improvement framework that follows KAIZEN philosophy, which poses that big results come from many small changes accumulated over 
time (Kazien Institute, 2015). Starting with basic lean in small firms and improving its application could improve the way of thinking and work for the whole organisation.

- The framework will enhance the internal communication in both vertical and horizontal levels by which the staff relationship will enhance, and Lean knowledge will distribute across different departments of the organisation (Wilkinson, Dundon and Grugulis, 2007).

- The framework cultivates fact-based thinking to SMEs and results in better understanding, commitments and control of the external and internal environment of the business which assures long-term survival.

- The framework is easy to understand; it consists of eight logical and connected steps that gradually guide the enterprise to overall improvements. The model is rather generic, long-term oriented and adaptable to various conditions considering the resource, time and limitations of SMEs.

\section{7- Applications of LEBM framework}

The framework of this study would prove highly relevant and useful to establish a successful implementation of the lean approach to increasing organisational effectiveness and efficiency of the small businesses. It can provide advantages in many cases.

- The framework originally developed to assist small manufacturing organisations in increasing awareness and closing the gaps in lean implementation in the journey towards the excellent world-class levels.

- The framework can be used as a self-assessment model to determine the degree of readiness for Lean approach adoption.

- Application of the framework can develop a culture of lean thinking through the continuous evaluation of the performance in the different managerial areas of the organisation. Thus, with the iteration of the framework, a further step towards excellent performance can be taken.

- The framework considered the limitation of SMEs, but a wide range of its criteria such as in leadership; strategic planning, process management, human resource and knowledge management make it applicable for the large organisations as well. 
- Based on the flexibility of criteria of LEBM, with slight changes, the framework can be applied to other sectors such as health, education, banking, tourism, telecommunication and public sector's organisations.

\section{8- Conclusion}

Since reaching excellent performance in developing economies is a far end and strategic objective for SMEs, the quest needs a deep understanding of advanced management approaches and full commitment to the comprehensive methodologies. It is believed that with a combination of Lean techniques into the criteria of MBNQA model outstanding levels of performance can be attained in both manufacturing and excellence extends. It is noticeable that the effective implementation of the two methodologies in an integrated manner will generate improvements in all seven areas of the organisation which results in actual changes in the attitudes of doing business to the long extent. It is worth to mention that, in general, the expected improvements by LEBM framework will take time; reaching excellent performance cannot happen overnight. However, deep understanding, full commitment and direct involvement of the top managers, supported with across training, education and empowerment of the workforce will facilitate the change procedures and maximise the LEBM framework outcomes.

The contextual LEBM model proposed can easily be applied to manufacturing SMEs to promote organisational performance. It can also be used to verify the degree of maturity of the company, determine its readiness towards Lean application and highlight opportunities for further improvements within the covered areas by the framework. So far, it is valuable to adopt the framework in different circumstances to explore the efficient results by doing experiments in real life and justify the reliability and validity of the framework. Real life case studies also can be conducted to provide a deep understanding of Lean application and its barriers within small businesses in developing countries. The empirical studies can be extended to cover moderator variables such as national culture, working conditions, personal value of the employees, supplier relationship management to examine their impacts on the lean adoption and business performance at the same time.

\section{References}

Achanga, P., Shehab, E., Roy, R. and Nelder, G. (2006), "Lean Manufacturing for SMEs: enabling rapid response to demand changes", Proceeding of the 15th International Conference on 
Engineering Design, Australi, Melbourne, 15-18, August 2005.

Ahuja, I. P. S. and Khamba, S. J.(2008), "Total productive maintenance: literature review and directions", International Journal of Quality and Reliability Management, Vol. 25 No. 7, pp. 709756.

Aiken, C. and Keller, S. (2009), "The irrational side of change management", McKinsey Quarterly, Vol. 2, June, pp.100-109.

Aken, E. M., Farris, J. A., Glover, W. J., Letens, G. (2010), "A framework for designing, managing, and improving Kaizen event programs", International Journal of Productivity and Performance Management, Vol. 59 No. 7, pp. 641-667.

Al Amin, M. (2013), "A Systematic Approach For Selecting Lean Strategies And Assessing Leanness In Manufacturing Organisations", PhD. Thesis, Queensland University of Technology, Brisbane City, Australia.

Alaskari, O., Ahmad M.M., Dhafr, N., Pinedo-Cuenca, R. (2012), "Critical Successful Factors (CSFs) for Successful Implementation of Lean Tools and ERP Systems", Proceedings of the World Congress on Engineering, 2012, July 4 - 6, London, U.K.

Alhuraish, I., Robledo, C. and Kobi, A. (2014), "Key Success Factors of Implementing Lean Manufacturing and Six Sigma”, 17th Toulon-Verona International Conference, Liverpool, England, August 28-29, 2014.

Alkhoraif, A., Rashid, H. And McLaughlin, P. (2018), "Lean Implementation in Small and Medium Enterprises: Literature review", Operation Research Perspectives, https://doi.org/10.1016/j.orp. 2018. 100089.

AlManei, M., Salonitis, M. And XU, y. (2017), "Lean implementation frameworks: the challenges for SMEs" [online]. Procedia CIRP, Vol. 63, pp. $750-755$.

Andersson, R., Eriksson, H. and Torstensson, H. (2006), "Similarities and differences between TQM, six sigma and lean", The TQM Magazine, Vol. 18 No. 3, pp. 282-296.

Antosz, K. and Stadnicka, D. (2017), " Lean Philosophy Implementation in SMEs - Study Results", Procedia Engineering, Vol. 182, pp.25-32.

Anvari, A., Zulkifli, N., Yusuff, R., Hojjati, M., Ismail, Y. (2011), "A proposed dynamic model for a lean roadmap", African Journal of Business Management, Vol. 5 No.16, pp. 6727-6737.

Baker, P. (2002), "Why is lean so far off?" Works Management, Vol. 55, pp. 26-29.

Balles, M. (2005), "Lean attitude-lean application often fail to deliver the expected benefits but could the missing link for successful implementations be attitude?", IEE Manuf. Eng, Vol. 84, pp.1419.

Belhadi, A., Touriki, F. E. And ElFezazi, S. (2018), "Lean Implementation in Small and Medium Enterprises in Less Developed Countries: Some Empirical Evidence From North Africa", Journal of Small Business Management, Vol. 56, Issue 1, pp. 132-153.

Bhamu, J. and Sangwan, K.S. (2014), "Lean manufacturing: literature review and research issues", International Journal of Operations and Production Management, Vol. 34 No. 7, pp. 876-940.

Bhuiyan, N. and Baghel, A. (2005), "An Overview of Continuous Improvement: From the Past to the Present", Measurement Decision, Vol. 43 No.5, pp 761-771.

Bilhadi, A., Touriki, F. E., Fezazi, S.E. (2016), "A Framework for Effective Implementation of Lean Production in Small and Medium-sized Enterprises", Journal of Industrial Engineering and Management, Vol. 9 No. 3, pp.781-810.

Blazey, M. and Grizzell, P. (2014), "Alignment of Baldrige with Six Sigma, Lean Thinking, and Balanced Scorecard", Insights to Performance Excellence 2014, American Society for Quality, Quality Press, USA. 
Bozdogan, K. (2010), "Integration of the Lean Enterprise System, Total quality management and Six Sigma", Encyclopedia of Aerospace Engineering.

BPEP (Baldrige Performance Excellence Programme) (2013), "Baldrige FAQs", available at :https: //www.nist.gov. (accessed 24 May 2017)

Chelangat, B. (2016), "Critical Success Factors (CSFs) For Implementation of Lean Six Sigma in Commercial Banks in Kenya", Journal of Business and Management, Vol. 18, Issue 12, pp. 2330.

Costa, L. B. M., Filho, M. G., Fredendall, L. D. and Paredes, F. J. G. (2018), " Lean, Six Sigma and Lean Six Sigma in The Food Industry: A systemic Literature review", Trends in Food Science \& Technology, Vol. 82, pp. 122-133.

Crute, V., Ward, Y., Brown, S., and Graves, A. (2003), "Implementing Lean in aerospace Challenging the assumptions and understanding the challenges", Technovation, Vol. 23, pp. 917-928.

Dahlgaard, J.J. and Dahlgaard-Park, S.M. (2006), "Lean production, six sigma quality, TQM and company culture", The TQM Magazine, Vol.18 No. 3, pp. 263-281.

DeVries, J. (2014), "Lean Healthcare Integration with Baldrige criteria", Lean Healthcare Exchange, available at: http://www. healthcareexchange.com. (accessed 16 October 2016)

Emiliani, B. (2008), "Real Lean: The Keys to Sustaining Lean Management", Vol. 3, Wethersfield, CT. USA: The Centrer For Lean Business Management, LLC.

Esfandyari, A. and Osman R. O. (2010), "Success and failure issues to lead lean manufacturing implementation", Proceedings of 4th International Management Conference, Copenhagen, Denmark, 23-24, May, 2010.

Fischer, B (2010), "The "Skinny" on Baldrige Versus Lean", available at: https://www.nistbaldrige.blogs.govdelivery.com. (accessed 16 October 2017)

Golicic, S. L., and Meland, S. S. (2007), "Size might matter a case study of lean implementation in an SME", Society for Marketing Advances Proceedings, pp. 261-264.

Grizzell, P. and Blazey, M. (2006), "Alignment of Baldrige with Six Sigma, Lean Thinking, and Balanced Scorecard", Insights to Performance Excellence 2004, An Inside Look at the 2004 Baldrige Award Criteria, American Society for Quality, USA.

Gupta, S. and Jain, S. K. (2013), "A literature review of lean manufacturing", International. Journal of Management Science and Engineering Management, Vol. 8 No. 4, pp. 241-249.

Halim, N. H. A., Jaffar, A., Yusoff, N. and Naufal, A. (2013), " Case Study: The Methodology of Lean Manufacturing Implementation", Applied Mechanics and Materials, Vol. 393, pp 3-8.

Hayes, B. J. (2005), "Assessing for lean six sigma implementation and success. Six Sigma Advantage", Available at: http://software.isixsigma.com. (accessed 14 September 2017)

Jasti, N. V. and Kodali, R. (2014), "A literature review of empirical research methodology in lean manufacturing", International Journal of OperationsandProduction Management, Vol. 34 No. 8 , pp. $1080-1122$.

Jedynak, P. (2015), "Lean management implementation: Determinant factors and experience", Jagiellonian Journal of Management, Vol. 1 No. 1, pp. 51-64.

Kaizen Instituet (2017), "Improve what you have", available at <https://www.kaizen.com>. (accessed 13 August 2017)

Karim, A. and Arif-Uz-Zaman, K. (2013), " A methodology for effective implementation of lean strategies and its performance evaluation in manufacturing organizations", Business Process Management Journal, Vol. 19 No. 1, pp. 169-196.

Knol, W. H., Slomp, J., Schouteten, R. L., J. and Lauche, K. (2018), " Implementing lean practices in 
manufacturing SMEs: testing 'critical success factors' using Necessary Condition Analysis", International Journal of Production Research, Vol. 56 No.11, pp. 3955-3973

Kumar. S. (2014), "Lean Manufacturing and its Implementation", International Journal of Advanced Mechanical Engineering, Vol. 4 No. 2, pp. 231-238.

Mahmud, N. and Hilmi, M. F. (2014), "TQM and Malaysian SMEs Performance: The Mediating Roles of Organization Learning", Procedia - Social and Behavioral Sciences, Vol.130, pp. 216 - 225.

Mamat, R. C., Deros, B, M., Ab Rahman, M. N., Omar, M. K., Abdullah, S. (2015), " Soft Lean Practices For Lean Production System Implementation Successful In Malaysia Automotive SMEs: A Proposed Framework", Journal Teknologi, Vol. 72, Issue 27, pp. 141-150.

Marodin, G. A. and Saurin, T. A. (2013), "Implementing lean production systems: research areas and opportunities for future studies", International Journal of Production Research, Vol. 51, issue 22, pp.6663-6680.

Martínez-Jurado, P. J., \& Moyano-Fuentes, J. (2014), "Key determinants of lean production adoption: Evidence from the aerospace sector", Production Planning \& Control, Vol. 25, 4, pp. 332-345.

Mason, R., Hu, Q., Williams, S. J. and Found, P. (2015), "Lean implementation within SMEs: a literature review", Journal of Manufacturing Technology Management, Vol. 26 No. 7, pp.9801012.

Matt, D. and Rauch, E. (2012), "Implementation of Lean Production in Small-Sized Enterprises", Procedia CIRP, Vol. 12, pp. 420-425.

MBNQA The Foundation for the Malcolm Baldrige National Quality Award MBNQA (2017 a), "History", available at:http://www.nist.gov. (accessed 26 August 2017)

Mendes, L. and Lourenço, L. (2014), "Factors that hinder quality improvement programs' implementation in SME: Definition of a taxonomy", Journal of Small Business and Enterprise Development, Vol. 21 No. 4, pp.690-715.

Miina, A., Saat, M., and Kolbre, E. (2013), "Critical Success Factors of Lean Thinking Implementation Process: Example of Estonian Manufacturing Companies", 3rd international conference Economies of Central and Eastern Europe (ECEE), Tallinn, Estonia, 12-14, July 2011.

Minh, D. M., Nguyen, N. D., Tuan, L. A. (2015), "Framework of Critical Success Factors for Lean Implementation in Vietnam Manufacturing Enterprises", Journal of Science: Economic and Business, Vol. 31, No. 5E, pp. 33-41.

Mostafa, S., Dumrak, J., and Soltan, H. (2013), "A framework for lean manufacturing implementation", Production and Manufacturing Research: An Open Access Journal, Vol. 1 No. 1, pp. 44-64.

Motwani, J. (2003), "A business process change framework for examining lean manufacturing: a case study", Industrial Management and Data Systems, Vol.103 No. 5, pp. 339-346.

Netland, T. H. (2016), "Critical success factors for implementing lean production: the effect of contingencies", International Journal of Production Research, Vol. 54 No. 8, pp. 2433-2448.

Nguyen, D.M. (2015), "A New Application Model of Lean Management in Small and Medium Sized Enterprises", International Journal Simul Model, Vol.14 No. 2, pp. 289-298.

Nidhin, K., Ramkumar, P. N., Satish, K. P. (2014), "Manufacturing Competitiveness through Lean Principles - Analysis of Readiness Level and Comparison in Small and Medium Enterprises by Identification and Modeling the Critical Success Factors", International Journal of Scientific \& Engineering Research, Vol. 5, Issue. 8, pp. 635-640.

NIST (2015), "Baldrige Excellence Framework", available at https://www.nist.gov. (accessed 25 October 2017)

Nordin, N., Md Deros, B., and Abd Wahab, D. (2010), "A Survey on Lean Manufacturing Implementation in Malaysian Automotive Industry", International Journal of Innovation, 
Management and Technology, Vol.1 No. 4, pp.374-380

Okay, S. and Semiz, S. (2013), "The effects of ISO 9000 quality management system implementation in small and medium-sized textile enterprises: Turkey experience", African Journal of Business Management, VI. 7 No. 42, pp. 4311-4322.

Okhovat, M. A., Ariffin, M. K., Taravatsadat Nehzati, T. and Hosseini, S. A. (2012), "Development of world-class manufacturing framework by using six-sigma, total productive maintenance and lean", Scientific Research and Essays, Vol. 7 No. 50, pp. $4230-4241$.

Ottar, B., Tim, G., Landeghem, V., and Hendrik (2011), "Challenges and Success Factors For Implementation Of Lean Manufacturing In European SMEs", Proceedings of $3^{\text {rd }}$ MITIP, Trondheim, Norway, 22-24, June, 2011.

Papadopoulou, T. C. and Ozbayark, M. (2005), "Leanness experiences from the Journey to Date", Journal of Manufacturing Technology Management, Vol. 16 No. 7, pp. 784-807.

Parast, M. M. and Jones, F. C. (2006), "A Relationship between Six Sigma and Malcolm Baldrige Quality Award", Publication of the University of Texas at Arlington, USA.

Pearce, A., Pons, D. and Neitzert, T. (2018), "Implementing lean-Outcomes from SME case studies", Operations Research Perspectives 5 (2018), pp. 94-104.

Reigado, R. C. and Bento, C. G. V.(2015), "Planning Lean Manufacturing Implementation: A Case Study in A Scottish Engineering", 34th National Meeting of Production Engineering,13-16 October 2015, Fortaleza, Brazil.

Rose, A. N. M., Deros, B. M., Rahman, M. N. A. (2014), "Critical Success Factors for Implementing Lean Manufacturing in Malaysian Automotive Industry", Research Journal of Applied Sciences, Engineering and Technology, Vol. 8 No. 10, pp. 1191-1200.

Rose, A.M.N. , Deros, B.Md., Rahman, M.N.Ab. and Nordin, N. (2011), "Lean manufacturing best practices in SMEs", Proceedings of the 2011 International Conference on Industrial Engineering and Operations Management, Kuala Lumpur, Malaysia, 22-24, January, 2011.

Roslin, E. N. and Shahadat, S. A. M. (2014), "A Conceptual Model for Full-Blown Implementation of Lean Manufacturing System in Malaysian Automotive Industry", International Conference on Industrial Engineering and Operations Management Bali, Indonesia, January 7 - 9, 2014, pp. 1309-1315.

Sahoo, S. and Yadav, S., (2018), "Lean implementation in small-and medium-sized enterprises: An empirical study of Indian manufacturing firms", Benchmarking: An International Journal, Vol. 25 No. 4, pp.1121-1147.

Saunders, M., Lewis, P. and Thornhil, A. (2009), "Research Methods for Business Students", 5th ed, Pearson Education Limited, UK.

Shah, R. and Ward, P.T. (2003), "Lean manufacturing: context, practice bundles, and performance", Journal of Operations Management, Vol. 21, pp. 129-149.

Sharma, M. and Kodali, R. (2008), "TQM implementation elements for manufacturing excellence", The TQM Journal, Vol. 20 No. 6, pp. 599-621.

Shehab, S, A., Habib, M. A. and nawandy, A. (2017), "The Small and Medium Enterprises (SMEs) in The Kurdistan Region Government-Iraq", Qalaat Zanist Scientific Journal, Vol. 2, No. 3, pp. 273-292.

Sieckmann, F., Ngoc, H. N., Helam, R. and Kohl, H. (2018), " Implementation of Lean Production System in Small and Medium Sized Pharmaceutical Enterprises", Procedia Manufacturing 21 (2018), pp. 814-821.

Singh, B., Garg, S.K., Sharma, S.K. and Grewal, C. (2010), "Lean implementation and its benefits to production industry", International Journal of Lean Six Sigma, Vol. 1 No. 2, pp. 157-168. 
Soare, P. (2012), "Opportunities for driving continuous improvement through TQM, lean and six sigma within business process management", The 6th International management conference, Bucharest: Romania, 15-16, November 2012.

Stake R. (2006), "Multiple Case Study Analysis", New York: The Guilford Press.

Tatsana-lam, W. and Ngaoprasertwong, J. (2013), "A Comparison of Process Improvement between Lean and Lean-TQM Approach", Global Engineering, Science and Technology Conference, Singapore, 3-4, October, 2013, pp.1-9.

Tickle, M., Mann, R., Adebanjo, D. (2016), "Deploying business excellence - success factors for high performance", International Journal of Quality and Reliability Management, Vol. 33 No. 2, pp.197-230.

Uddin, A. (2011), "A conceptual design for lean manufacturing system and its implementation in SME and LE", Robotics and Factories of the Future proceedings of the 26th International Conference on CAD/CAM, Kuala Lumpur, pp. 289-296.

Upadhye, U., Deshmukh, S. G. and Garg, S. (2010), "Lean Manufacturing for Sustainable Development", Global Business and Management Research, Vol. 2 No. 1, pp. 125-137.

Wanitwattanakosol, J. and Sopadang, A. (2011), "A framework for implementing lean manufacturing system in small and medium enterprises", Applied Mechanics and Materials, Vols 110-116, pp. 3997-4003.

Wilkinson A., Dundon, T. and Grugulis, I. (2007), "Information but not consultation: exploring employee involvement in SMEs", International Journal Of Human Resource Management, Vol. 18 No. 7 , pp. $1279-97$.

Wong, W. and Cheah, C. (2011), "Linking Organizational Culture to Lean Implementation in the Malaysian Electrical and Electronics Industry: A Conceptual Framework", Advances In Management, Vol. 4 No. 4, pp. 50-57.

Wong, Y. and Wong, K. (2011), "Approaches and Practices of Lean Manufacturing: The Case of Electrical and Electronics Companies", African Journal of Business Management, Vol. 5 No. 6 , pp. 2164-2174.

Wong, Y.C., Wong, K.Y. and Ali, A. (2009), "A study on lean manufacturing implementation in the Malaysian electrical and electronics industry", European Journal of Scientific Research, Vol. 38 No. 4, pp. 521-535.

Yadav, O. P., Nepal, B., Goel, P. S., Jain, R. and Mohanty, R. P. (2010), "Insights and Learnings from lean manufacturing implementation practices", International Journal of Services and Operations Management, Vol. 6 No. 4, pp. 398-422.

Yew, O. F. (2016), "The Mediating Role of Lean Engagement on Lean Practices and Business Excellence in Malaysia Electrical and Electronics Companies", International Journal of Academic Research in Economics and Management Sciences, Vol. 5 No. 2, pp.35-45.

Zargun, S. and Al-Shaab (2014), "Critical Success Factors for Lean Manufacturing: A Systematic Literature Review An International Comparison between Developing and Developed Countries", Advanced Materials Research, Vol. 845, pp. 668-681. 


\begin{tabular}{|c|c|c|c|c|c|c|c|c|c|c|c|c|c|c|c|c|c|c|c|c|c|}
\hline LEBM drivers & 1 & 2 & 3 & 4 & 5 & 6 & 7 & 8 & 9 & 10 & 11 & 12 & 13 & 14 & 15 & 16 & 17 & 18 & 19 & 20 & \\
\hline Long-term vision & $\times$ & & $\times$ & & $x$ & & $x$ & $x$ & $\times$ & & & & $x$ & & $x$ & & & & $x$ & $x$ & 10 \\
\hline Reward and motivation & $x$ & & & & & $x$ & & $x$ & $x$ & $\times$ & $\times$ & & & $x$ & & & $x$ & $x$ & & $x$ & 10 \\
\hline Top management commitment & $\times$ & $x$ & $\times$ & & $x$ & $x$ & $x$ & $x$ & $\times$ & $\times$ & $\times$ & $x$ & & $\times$ & $x$ & $\times$ & $x$ & $x$ & & & 16 \\
\hline Management involvement & $\times$ & & $\times$ & & $x$ & & $x$ & $x$ & & & & & $x$ & & & & & & $x$ & $\times$ & 8 \\
\hline Leading process simplification & & & & $\times$ & & & & $\times$ & $\times$ & & $\times$ & & & & & & & & & $\times$ & 5 \\
\hline Customer data collection & $x$ & & & & $x$ & & $x$ & $x$ & & $\times$ & & & $x$ & $x$ & & & & $x$ & & & 8 \\
\hline Quick feedback responsiveness & $\times$ & & & & $x$ & & & & & & & & & & & & & & & & 3 \\
\hline Customer involvement & & $x$ & & & & $\times$ & $x$ & $x$ & & $\times$ & & & $x$ & $x$ & & $\times$ & & $x$ & & & 9 \\
\hline Clear lean strategies & $x$ & & $x$ & & $x$ & $x$ & $x$ & $x$ & $x$ & & & $x$ & $x$ & $x$ & $x$ & & & $x$ & $x$ & $x$ & 14 \\
\hline Use of right Lean tools & $x$ & & & & & & & $x$ & $\times$ & & & $x$ & & & & & & & $x$ & & 5 \\
\hline Manufacturing planning & $\times$ & & & & & & & & & & & & & $\times$ & $x$ & & & $x$ & & $x$ & 6 \\
\hline Delegated responsibilities & $\times$ & & & & & & & & $x$ & & & & & & & & & $x$ & & & 4 \\
\hline Improvement suggestion system & $\times$ & & & & & & & & & & & & & & & $\times$ & & & & & 2 \\
\hline Influence over suppliers & $\times$ & $x$ & & & $x$ & & $x$ & & $x$ & $\times$ & & & & & & $\times$ & & $\times$ & & & 9 \\
\hline Automation & & & & $\times$ & & & & & & & & & & & & & & $x$ & & & 3 \\
\hline Training and educating & $\times$ & $x$ & & & $x$ & $\times$ & $x$ & & $x$ & $\times$ & $x$ & $x$ & $x$ & $\times$ & & & $x$ & $\times$ & $x$ & $x$ & 15 \\
\hline Total employees involvement & $\times$ & $x$ & $\times$ & & $x$ & $x$ & & & $x$ & $\times$ & $x$ & & $x$ & $\times$ & & $\times$ & $x$ & $\times$ & & $x$ & 15 \\
\hline Workforce empowerment & $\times$ & $x$ & & $\times$ & & & $x$ & & & & $x$ & $x$ & & & & & $x$ & $x$ & & & 8 \\
\hline Teamwork & $\times$ & & & & $x$ & & & $x$ & & $\times$ & & & & & & & $x$ & & $x$ & $x$ & 7 \\
\hline Deep understanding & $\times$ & & $\times$ & & & $x$ & & & & & & $x$ & & $\times$ & $x$ & & & $\times$ & $\times$ & & 7 \\
\hline Communication and knowledge sharing & $\times$ & & $\times$ & & $x$ & $\times$ & $x$ & & & & $x$ & & $x$ & $x$ & & & $x$ & $\times$ & & $\times$ & 11 \\
\hline Financial resource allocation & $\times$ & & $\times$ & & $x$ & $\times$ & $x$ & & $x$ & & & $x$ & $x$ & $\times$ & & $\times$ & & $x$ & $x$ & $x$ & 13 \\
\hline
\end{tabular}

1: Zargun and Al-Ashaab, 2014; 2: Rose et al., 2014; 3: Al-Manei et al., 2017: Pearce et al., 2018; 5: Alkhoraifet al., 2018; 6: Minh et al., 2015; 7: Knol, et al., 2018; 8: Alhuraish et al. 2014; 9: Alaskari et al., 2012; 10: Mamat et I, 2015; 11: Marodin and Sauriin, 2013; 12 Sahoo and Yadav, 2018; 13: Martínez-Jurado and Moyano-Fuentes, 2014; 14: Sieckmann, 2018; 15 Reigado and Bento, 2015; 16 : Nidhin, 2014; 17: Costa, et al., 2018; 18: Chelangat, 2016; 19: Bilhadi et al., 2018; 20: Netland, 2016.

Table 1 Critical success factors of LM implementation 


\begin{tabular}{|c|c|c|c|}
\hline Author & Description & Methodology & Comments \\
\hline $\begin{array}{l}\text { Belhadi et } \\
\text { al., } 2016\end{array}$ & $\begin{array}{l}\text { An integrated framework } \\
\text { encompasses three phases with } 16 \\
\text { steps where each phase contained } \\
\text { different tools and CSF to support } \\
\text { Lean strategies implementation in } \\
\text { SMEs. }\end{array}$ & $\begin{array}{l}\text { Literature } \\
\text { review and } \\
\text { multiple case } \\
\text { studies }\end{array}$ & $\begin{array}{l}\text { No performance indicators } \\
\text { described }\end{array}$ \\
\hline $\begin{array}{l}\text { Nguyen, } \\
2015\end{array}$ & $\begin{array}{l}\text { A management model wheel } \\
\text { includes three main elements ( } 5 \mathrm{~S} \text {, } \\
\text { Kaizen and visual control) with a } \\
\text { focus on deep understanding of Lean } \\
\text { benefits to support Vietnamese } \\
\text { SMEs for better Lean } \\
\text { implementation. }\end{array}$ & $\begin{array}{l}\text { Two rounds } \\
\text { of a survey } \\
\text { and follow- } \\
\text { up } \\
\text { interviews }\end{array}$ & $\begin{array}{l}\text { Sequences for implementing } \\
\text { Lean are not specified. } \\
\text { Lack of performance } \\
\text { measurements } \\
\text { Hard for beginners to start } \\
\text { up with the model }\end{array}$ \\
\hline $\begin{array}{l}\text { Roslin and } \\
\text { Shahadat, } \\
2014\end{array}$ & $\begin{array}{l}\text { A conceptual model of three } \\
\text { elements to aid Lean adoption in } \\
\text { Malaysia automotive parts } \\
\text { manufacturing industry. }\end{array}$ & $\begin{array}{l}\text { Literature } \\
\text { review }\end{array}$ & $\begin{array}{l}\text { Lack of adoption sequences } \\
\text { description } \\
\text { The relevant internal } \\
\text { stakeholders are not } \\
\text { specified }\end{array}$ \\
\hline $\begin{array}{l}\text { Mostafa et } \\
\text { al., } 2013\end{array}$ & $\begin{array}{l}\text { A conceptual project-based } \\
\text { framework of four phases including } \\
\text { conceptual phase, implementation } \\
\text { design phase, implementation and } \\
\text { evaluation phase, and the lean } \\
\text { transformation phase. A number of } \\
\text { Lean tools and practices are assigned } \\
\text { to each phase. }\end{array}$ & $\begin{array}{l}\text { Literature } \\
\text { review }\end{array}$ & $\begin{array}{l}\text { Complex structure with } 22 \\
\text { steps which is hard for SMEs } \\
\text { to follow } \\
\text { Needs highly-skilled } \\
\text { practitioners } \\
\text { Lack of total employees } \\
\text { involvement }\end{array}$ \\
\hline $\begin{array}{l}\text { Karim \& Arif } \\
\text { Uz-Zaman, } \\
2013\end{array}$ & $\begin{array}{l}\text { A systematic Lean implementation } \\
\text { methodology base on the five } \\
\text { principles of Womack and Jones } \\
\text { (1996) aimed at the application of } \\
\text { LM tools in the production processes } \\
\text { and developing continuous } \\
\text { improvement techniques within the } \\
\text { organisation. }\end{array}$ & $\begin{array}{l}\text { Literature } \\
\text { review and a } \\
\text { single case } \\
\text { study }\end{array}$ & $\begin{array}{l}\text { Highly-skilled employees } \\
\text { required } \\
\text { Complex structure compared } \\
\text { to SMEs limited resources }\end{array}$ \\
\hline $\begin{array}{l}\text { Halim et al., } \\
2013\end{array}$ & $\begin{array}{l}\text { A methodology of Lean } \\
\text { implementation based on Toyota's 8- } \\
\text { steps processes with methods and } \\
\text { Lean tools assigned to each step } \\
\text { aimed at optimising the } \\
\text { effectiveness of Lean practices in the } \\
\text { organisation. }\end{array}$ & Case study & $\begin{array}{l}\text { Needs specialist } \\
\text { practitioners } \\
\text { Designed for large } \\
\text { companies with huge } \\
\text { resources } \\
\text { Not suitable for beginners } \\
\text { companies with LM initiative }\end{array}$ \\
\hline $\begin{array}{l}\text { Anvari et al., } \\
2011\end{array}$ & $\begin{array}{l}\text { A project-based framework with five } \\
\text { steps to provide a dynamic approach } \\
\text { to Lean transmission in different } \\
\text { industries and a high variability } \\
\text { environment }\end{array}$ & $\begin{array}{l}\text { Literature } \\
\text { review }\end{array}$ & $\begin{array}{l}\text { Most activities are limited to } \\
\text { the top managers } \\
\text { Needs a lot of effort to } \\
\text { sustain the results }\end{array}$ \\
\hline Wong and & A framework covers LM principles, & Multiple & Applied to the high matured \\
\hline
\end{tabular}




\begin{tabular}{|c|c|c|c|}
\hline Wong, 2011 & $\begin{array}{l}\text { LM pre-request, LM activities and LM } \\
\text { tools to generate continuous } \\
\text { improvements in } 14 \text { different } \\
\text { production areas in Malaysian } \\
\text { Electrical and Electronic industry. }\end{array}$ & case studies & $\begin{array}{l}\text { organisation } \\
\text { No clear links between the } \\
\text { improvement areas }\end{array}$ \\
\hline Uddin 2011 & $\begin{array}{l}\text { A conceptual framework based on } \\
\text { different aspects of the strengths } \\
\text { and weaknesses of SMEs and LEs } \\
\text { aimed at supporting effective Lean } \\
\text { adoption }\end{array}$ & $\begin{array}{l}\text { Literature } \\
\text { review }\end{array}$ & $\begin{array}{l}\text { Not clear instruction for } \\
\text { adoption phases } \\
\text { No consideration for the } \\
\text { preparation phase } \\
\text { No clear links between the } \\
\text { elements of the framework }\end{array}$ \\
\hline $\begin{array}{l}\text { Wanitwatta } \\
\text { nakosol and } \\
\text { Sopadang, } \\
2011\end{array}$ & $\begin{array}{l}\text { A conceptual framework for Lean } \\
\text { transformation in SMEs with high- } \\
\text { variety and low-volume environment } \\
\text { including two phases with three } \\
\text { interrelated components in the first } \\
\text { phase }\end{array}$ & $\begin{array}{l}\text { Literature } \\
\text { review }\end{array}$ & $\begin{array}{l}\text { Lack of total employees } \\
\text { involvement } \\
\text { Lack of implementation } \\
\text { instructions for internal } \\
\text { stakeholders }\end{array}$ \\
\hline $\begin{array}{l}\text { Rose et al., } \\
2010\end{array}$ & $\begin{array}{l}\text { A conceptual framework for LM } \\
\text { implementation in SMEs comprised } \\
\text { of top management commitment, } \\
\text { lean practices, external support and } \\
\text { process evaluation. }\end{array}$ & $\begin{array}{l}\text { Literature } \\
\text { review }\end{array}$ & $\begin{array}{l}\text { Lack of implementation } \\
\text { methodology description } \\
\text { No clear links between the } \\
\text { elements of the framework } \\
\text { No internal stakeholders of } \\
\text { the Lean tools in each } \\
\text { practice are specified }\end{array}$ \\
\hline $\begin{array}{l}\text { Aken et al., } \\
2010\end{array}$ & $\begin{array}{l}\text { A framework to assist the design, } \\
\text { management and sustain of short- } \\
\text { term Kaizen events in the } \\
\text { organisation which it can be applied } \\
\text { within any lean transformation } \\
\text { initiative. }\end{array}$ & $\begin{array}{l}\text { Literature } \\
\text { review and } \\
\text { multiple } \\
\text { case studies }\end{array}$ & $\begin{array}{l}\text { Needs highly-skilled } \\
\text { managers } \\
\text { No Lean tools and CSF } \\
\text { described } \\
\text { Team-based event } \\
\text { Not suitable for SMEs } \\
\text { Cannot be extended easily }\end{array}$ \\
\hline
\end{tabular}

Table 2 Frameworks for LM implementation within SMEs 


\begin{tabular}{|l|l|l|}
\hline \multicolumn{1}{|c|}{ Concept } & \multicolumn{1}{|c|}{ MBNQA } & \multicolumn{1}{c|}{ Lean } \\
\hline Origin & $\begin{array}{l}\text { The evolution of quality in the } \\
\text { USA }\end{array}$ & $\begin{array}{l}\text { The quality revolution in Japan and } \\
\text { Toyota }\end{array}$ \\
\hline Theory & $\begin{array}{l}\text { Focus on customers through } \\
\text { Continuous improvement }\end{array}$ & $\begin{array}{l}\text { Focus on the customer through waste } \\
\text { elimination. }\end{array}$ \\
\hline Process view & Improve and uniform processes & Improve the flow of processes \\
\hline Approach & $\begin{array}{l}\text { Teamwork and group } \\
\text { commitment. }\end{array}$ & $\begin{array}{l}\text { Respect for people, training and } \\
\text { change management. }\end{array}$ \\
\hline Methodology & Plan, Do, Control, Act & $\begin{array}{l}\text { Defining customer value, Value } \\
\text { stream, Analysis, Flow, Pull, } \\
\text { Perfection. }\end{array}$ \\
\hline Tools & $\begin{array}{l}\text { Analytical and statistical based } \\
\text { tools }\end{array}$ & Analytical based tools. \\
\hline Focus & Excellence performance & Efficiency improvement. \\
\hline Primary effects & Increase customer satisfaction & Reduce lead time, cost and waste \\
\hline $\begin{array}{l}\text { Secondary } \\
\text { effects }\end{array}$ & $\begin{array}{l}\text { Achieves customer loyalty and } \\
\text { improves performance }\end{array}$ & $\begin{array}{l}\text { Reduces inventory, increases } \\
\text { productivity and customer satisfaction }\end{array}$ \\
\hline Criticism & $\begin{array}{l}\text { No tangible improvements, } \\
\text { resource-demanding, the } \\
\text { unclear notion }\end{array}$ & $\begin{array}{l}\text { Flexibility reduction which causes } \\
\text { congestion in the supply chain. }\end{array}$ \\
\hline $\begin{array}{l}\text { Financial } \\
\text { Returns }\end{array}$ & $\begin{array}{l}\text { By reducing wastes and } \\
\text { production cost }\end{array}$ & $\begin{array}{l}\text { Through better performance and a } \\
\text { higher level of competitiveness. }\end{array}$ \\
\hline Time required & $\begin{array}{l}\text { A long-term view and } \\
\text { commitment }\end{array}$ & $\begin{array}{l}\text { Long-term culture and attitudes } \\
\text { change }\end{array}$ \\
\hline
\end{tabular}

Table 3 The harmony between MBNQA and LM thinking

( Source: Anderson et al., 2006)

\begin{tabular}{|l|l|l|l|}
\hline \multicolumn{1}{|c|}{ General Information } & \multicolumn{1}{|c|}{ Company A } & \multicolumn{1}{c|}{ Company B } & \multicolumn{1}{c|}{ Company C } \\
\hline The main type of industry & Tile & Plastic & Food and drink \\
\hline Age of the company & 23 & 9 & 12 \\
\hline Number of full-time employees & 10 & 19 & 45 \\
\hline Ownership & Private & Partnership & Part of a bigger group \\
\hline Quality system of the company & $\begin{array}{l}\text { Conformity of Iraqi } \\
\text { standardisation } \\
\text { and quality control }\end{array}$ & $\begin{array}{l}\text { Conformity of Iraqi } \\
\text { standardisation and } \\
\text { quality control }\end{array}$ & ISO 9000-2008 \\
\hline The value of the company & $\$ 2,000,000$ & $\$ 3,500,000$ & $\$ 15,000,000$ \\
\hline Annual turnover & $\$ 800,000$ & $\$ 1,800,000$ & $\$ 2,500,000$ \\
\hline Area occupied & $4,600 \mathrm{~m}^{2}$ & $25,000 \mathrm{~m}^{2}$ & $52,500 \mathrm{~m}^{2}$ \\
\hline Company size & Small & Small & Medium \\
\hline Production technology followed & Italy & Italy, German, UK & $\begin{array}{l}\text { Turkey, Italy and } \\
\text { Germany }\end{array}$ \\
\hline
\end{tabular}

Table 4 Details of the companies which participated in the study 


\begin{tabular}{|c|l|c|c|c|}
\hline No. & Core values and concepts & Company A & Company B & Company C \\
\hline 1 & A systems perspective & $\times$ & $\checkmark$ & $\times$ \\
\hline 2 & Visionary leadership & $\times$ & $\checkmark$ & $\checkmark$ \\
\hline 3 & Customer-focused & $\checkmark$ & $\checkmark$ & $\checkmark$ \\
\hline 4 & Valuing people & $\checkmark$ & $\times$ & $\checkmark$ \\
\hline 5 & Organisational learning & $\checkmark$ & $\checkmark$ & $\checkmark$ \\
\hline 6 & Continuous improvement & $\times$ & $\times$ & $\times$ \\
\hline 7 & Managing for innovation & $\times$ & $\times$ & $\checkmark$ \\
\hline 8 & Management by fact & $\times$ & $\times$ & $\checkmark$ \\
\hline 9 & Ethics and transparency & $\checkmark$ & $\checkmark$ \\
\hline 10 & Challenges and flexibility & & & \\
\hline
\end{tabular}

Table 5 Core values of LM implementation within KRI-SMEs

\begin{tabular}{|r|l|c|c|c|}
\hline No. & Lean drivers & Company A & Company B & Company C \\
\hline 1 & Lean Leadership & $\times$ & $\times$ & $\checkmark$ \\
\hline 2 & Customer relationship & $\checkmark$ & $\checkmark$ & $\checkmark$ \\
\hline 3 & Strategic Planning & $\times$ & $\times$ & $\checkmark$ \\
\hline 4 & Continuous improvement & $\checkmark$ & $\checkmark$ & $\checkmark$ \\
\hline 5 & Human resource development & $\checkmark$ & $\checkmark$ & $\checkmark$ \\
\hline 6 & Organisational learning & $\times$ & $\checkmark$ & $\checkmark$ \\
\hline 7 & Process management & $\checkmark$ & $\checkmark$ & $\checkmark$ \\
\hline 8 & Business results & $\times$ & $\times$ & $\checkmark$ \\
\hline
\end{tabular}

Table 6 Drivers of LM implementation in KRI-SMEs 


\begin{tabular}{|c|c|c|c|c|}
\hline No. & LEBM drivers & Company $\mathrm{A}$ & Company B & Company C \\
\hline \multicolumn{5}{|c|}{ Critical Success Factors of Lean implementation in KRI-SMEs } \\
\hline 1 & Top management commitment & $\checkmark$ & $\checkmark$ & $\checkmark$ \\
\hline 2 & Management involvement & $\checkmark$ & $\checkmark$ & $x$ \\
\hline 3 & Clear lean strategies & $x$ & $x$ & $x$ \\
\hline 4 & Use of right Lean tools & $x$ & $x$ & $\checkmark$ \\
\hline 5 & Delegated responsibilities & $x$ & $\checkmark$ & $\checkmark$ \\
\hline 6 & Long-term vision & $\checkmark$ & $\checkmark$ & $\checkmark$ \\
\hline 7 & Reward and motivation & $\checkmark$ & $\checkmark$ & $\checkmark$ \\
\hline 8 & Training and educating & $x$ & $\checkmark$ & $\checkmark$ \\
\hline 9 & Total employees involvement & $\checkmark$ & $\checkmark$ & $\checkmark$ \\
\hline 10 & Workforce empowerment & $x$ & $x$ & $x$ \\
\hline 11 & Team-working & $\checkmark$ & $x$ & $x$ \\
\hline 12 & Deep understanding & $x$ & $x$ & $x$ \\
\hline 13 & Financial resource allocation & $x$ & $x$ & $\checkmark$ \\
\hline 14 & Customer involvement & $\checkmark$ & $\checkmark$ & $\checkmark$ \\
\hline 15 & $\begin{array}{l}\text { Communication and knowledge } \\
\text { sharing }\end{array}$ & $x$ & $x$ & $\checkmark$ \\
\hline 16 & Leading process simplification & $x$ & $x$ & $\checkmark$ \\
\hline 17 & Quick feedback responsiveness & $x$ & $x$ & $\checkmark$ \\
\hline 18 & Manufacturing planning & $x$ & $x$ & $\checkmark$ \\
\hline 19 & Improvement suggestion system & $x$ & $x$ & $\checkmark$ \\
\hline 20 & Influence over suppliers & $\checkmark$ & $\checkmark$ & $\checkmark$ \\
\hline \multicolumn{5}{|c|}{ Lean tools implemented in KRI-SMEs } \\
\hline 1 & Customer data collection & $x$ & $x$ & $\checkmark$ \\
\hline 2 & Wide-market products & $\checkmark$ & $\checkmark$ & $\checkmark$ \\
\hline 3 & PDCA cycle & $x$ & $x$ & $\checkmark$ \\
\hline 4 & Root cause analysis & $x$ & $\checkmark$ & $\checkmark$ \\
\hline 5 & Visualise stream chain & $x$ & $x$ & $x$ \\
\hline 6 & Cellular manufacturing & $x$ & $\checkmark$ & $\checkmark$ \\
\hline 7 & $5 S$ & $\checkmark$ & $\checkmark$ & $\checkmark$ \\
\hline 8 & Total productivity maintenance & $\checkmark$ & $\checkmark$ & $\checkmark$ \\
\hline 9 & Automation & $\checkmark$ & $\checkmark$ & $\checkmark$ \\
\hline 10 & Statistical process control & $x$ & $x$ & $\checkmark$ \\
\hline
\end{tabular}

Table 7 CSF and Lean tools adopted in KRI-SMEs 


\begin{tabular}{|l|c|c|c|}
\hline Problems & Company A & Company B & Company C \\
\hline Language barriers & $\checkmark$ & $\checkmark$ & $\checkmark$ \\
\hline Technology development & $\times$ & $\checkmark$ & $\times$ \\
\hline Company size & $\checkmark$ & $\checkmark$ & $\checkmark$ \\
\hline Organisational culture & $\checkmark$ & $\checkmark$ & $\checkmark$ \\
\hline Low qualified workers & $\times$ & $\times$ & $\checkmark$ \\
\hline Lack of management commitment & $\checkmark$ & $\checkmark$ & $\times$ \\
\hline Lack of time & $\checkmark$ & $\checkmark$ & $\times$ \\
\hline Lack of skills & $\checkmark$ & $\checkmark$ & $\times$ \\
\hline Lack of government support & $\times$ & $\times$ & $\checkmark$ \\
\hline Change resistance & $\checkmark$ & $\checkmark$ & $\times$ \\
\hline Lack of financial resources & $\checkmark$ & $\checkmark$ & $\times$ \\
\hline Lack of infrastructure services & $\checkmark$ & $\checkmark$ & $\times$ \\
\hline Work-related stress & $\checkmark$ & $\checkmark$ & $\checkmark$ \\
\hline Lack of awareness & $\checkmark$ & $\checkmark$ & $\checkmark$ \\
\hline Poor banking system & $\checkmark$ & $\checkmark$ & $\checkmark$ \\
\hline Market competition & $\checkmark$ & $\checkmark$ & $\times$ \\
\hline Legislation & & & \\
\hline
\end{tabular}

Table 8 Barriers of LM implementation within KRI-SMEs 
Figure $1 \mathrm{MBNQA}$ model for performance excellence (Source: nist.gov)

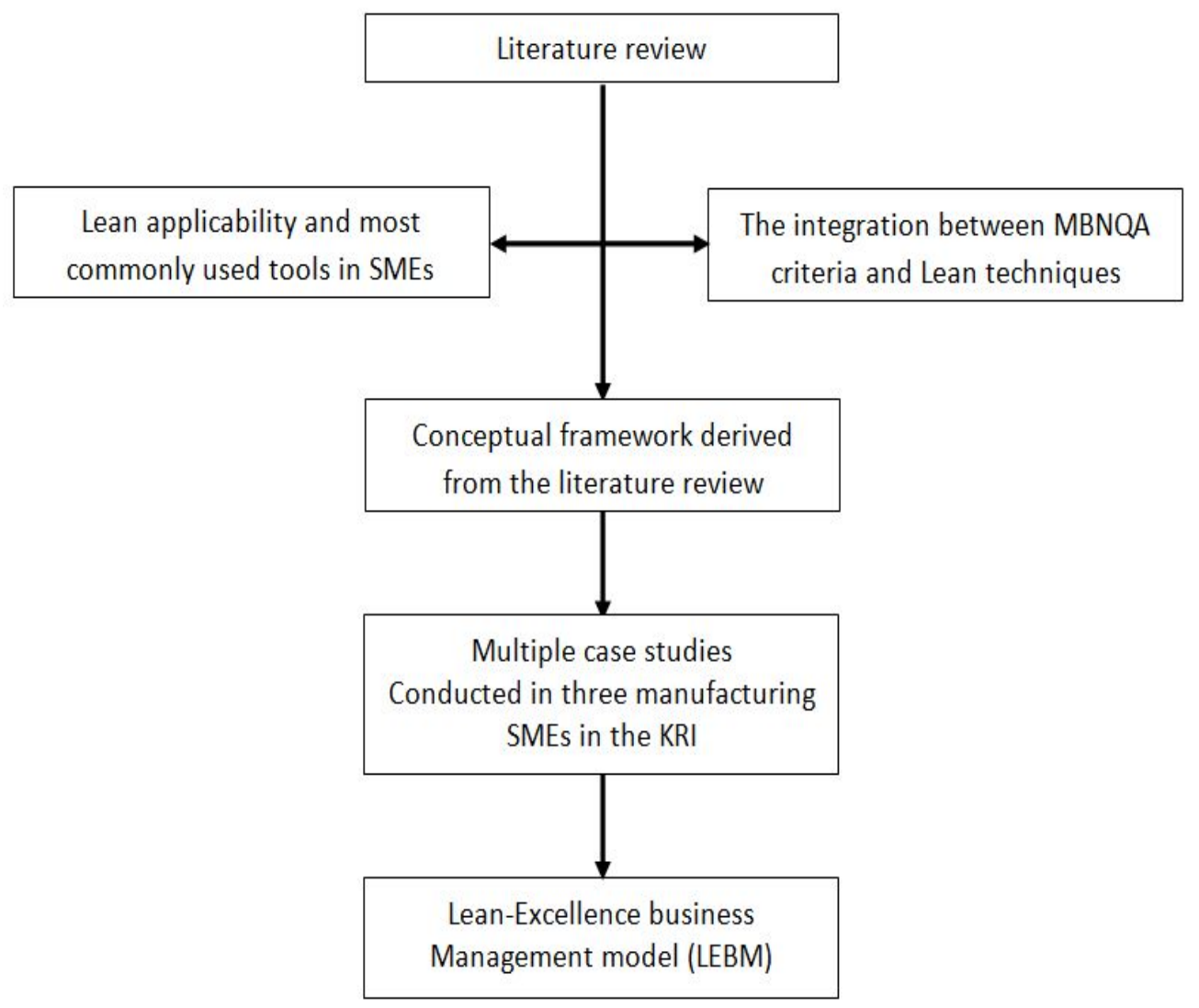

Figure 2 Research methodology

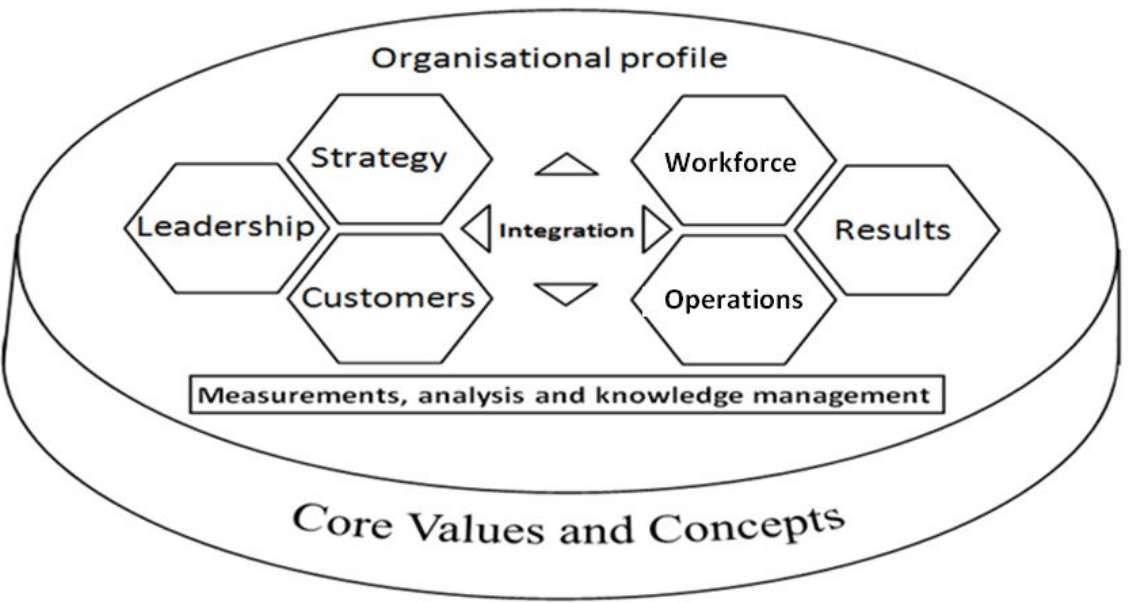

Management model (LEBM) 


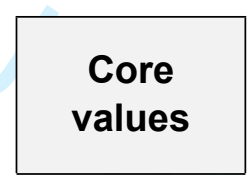

\begin{tabular}{|llll|}
\hline $\begin{array}{l}\text { Visionary leadership } \\
\text { improvement }\end{array}$ & Customer orientation & Learning and development & Continuous \\
& Challenges and flexibility & Respect for people & \\
\hline
\end{tabular}



Figure 3 LEBM Framework 